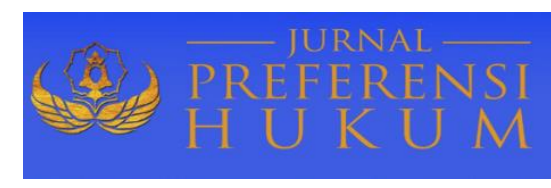

Jurnal Preferensi Hukum | ISSN: 2746-5039

Vol. 2, No. 1 - Februari 2021, Hal. 197-201| Available online at

https://www.ejournal.warmadewa.ac.id/index.php/juprehum

DOI: https://doi.org/10.22225/jph.2.1.3067.197-201

\title{
AKIBAT HUKUM PENEBANGAN HUTAN SECARA LIAR
}

\author{
Putu Ayu Irma Wirmayanti, Ida Ayu Putu Widiati, I Wayan Arthanaya \\ Fakultas Hukum Universitas Warmadewa, Denpasar-Bali, Indonesia
}

\begin{abstract}
Abstrak
Dahulu hutan Indonesia kaya akan keragaman dan berbagai jenis populasi di dalamnya akan tetapi saat ini hutan di Indonesia menjadi hutan yang terancam di dunia karena akibat dari perusakan hutan dengan menebang pohon secara liar. Penebangan hutan secara liar menjadi salah satu faktor dari kerusakan dalam kawasan hutan saat ini Penebangan liar tersebut berdampak negatif yang mengakibatkan hutan menjadi gundul. Meskipun sudah ada aturan yang mengatur mengenai larangan-larangan penebangan hutan secara liar tetap masih banyak juga para oknum yang melakukan penebangan pohon di hutan secara liar. Penelitian ini bertujuan untuk mnegetahui bentuk pengaturan tentang larangan penebangan hutan secara liar dan untuk mengetahui penerapan sanksi bagi pelaku penebangan hutan secara liar. Metode penelitian yang digunakan adalah metode penelitian hukum normatif, dengan studi kepustakaan dari bahan hukum primer dan sekunder. Hasil penelitian dapat disimpulkan bahwa: 1) Larangan-larangan penebangan hutan secara liar diatur dalam Undang-undang Kehutanan Nomor 41 Tahun 1999, Undang-undang Nomor 18 Tahun 2013 tentang Pencegahan dan Pemberantasan Perusakan Hutan dan Peraturan Pemerintah Perlindungan Hutan Nomor 28 Tahun 1985. 2) Sanksi-sanksi bagi pelaku yang melakukan penebangan liar dapat berupa sanksi perdata, sanksi administratif dan sanksi pidana. Dari hal tersebut masyarakat diharapkan agar lebih peduli terhadap lingkungan hidup, karena salah satu penyebab terjadinya bencana alam yaitu penebangan hutan secara liar.
\end{abstract}

Kata Kunci: Hutan; Penebangan Liar; Sanksi

\begin{abstract}
In the past, Indonesia's forests were rich in diversity and various types of population in it, but now forests in Indonesia are threatened forests in the world because of the result of forest destruction by illegal cutting of trees. Illegal logging is one of the factors in the damage to the forest area at this time. Illegal logging has a negative impact which causes the forest to become deforested. Even though there are regulations governing illegal logging prohibitions, there are still many people who cut trees in the forest illegally. This study aims to determine the form of regulation on the prohibition of illegal logging and to determine the application of sanctions for perpetrators of illegal logging. The research method used is normative legal research method, with literature study of primary and secondary legal materials. The results of the study can be concluded that: 1) Prohibitions on illegal logging are regulated in Forestry Law Number 41 of 1999, Law Number 18 of 2013 concerning Prevention and Eradication of Forest Destruction and Government Regulation of Forest Protection Number 28 of 1985. 2) Sanctions for perpetrators who carry out illegal logging can be in the form of civil sanctions, administrative sanctions and criminal sanctions. From this, the community is expected to be more concerned about the environment, because one of the causes of natural disasters is illegal logging.
\end{abstract}

Keywords: Forest; Illegal logging; Penalty

\section{PENDAHULUAN}

Indonesia merupakan Negara yang kaya akan sumber daya alam yang melimpah. Sumber daya alam yang ada memberikan banyak manfaat bagi keberlangsungan hidup manusia. Manusia berkewajiban untuk mempertahankan ketersediaan sumber-sumber daya alam itu secara terus menerus melalui suatu pengelolaan (Rahmadi, 2013:163). Saat ini mutu sumber daya alam sudah semakin menurun, masyarakat sudah seharusnya untuk menjaga pelestarian sumber daya alam. Sumber daya alam yang patut dijaga kelestariannya yakni salah satunya hutan. Peran dan kedudukan hutan sangat penting untuk menunjang pembangunan di Indonesia secara nasional (S, 2003:1). Dahulu hutan Indonesia kaya akan keragaman dan berbagai jenis populasi di dalamnya akan tetapi saat ini hutan di Indonesia menjadi hutan yang terancam di dunia karena akibat dari perusakan hutan dengan menebang pohon secara liar. Penebangan hutan secara liar menjadi salah satu faktor dari kerusakan dalam kawasan hutan saat ini (Iskandar, 2015:4-5). 
Berkaitan penebangan hutan, beberapa penelitian terdahulu telah dilakukan seperti Carvalho, Mendonça, Martins, \& Haugaasen (2020); Vardeman \& Runk (2020); Boyle, (2012); Sun, (2006); Supriatna et al., (2020); Tacconi, Rodrigues, \& Maryudi (2019). Penebangan liar semakin marak terjadi di hutan, khususnya di Indonesia. Penebangan hutan secara liar ini tidak hanya dilakukan oleh masyarakat yang ada di sekitaran hutan saja, namun terkadang hal tersebut juga dilakukan oleh para pengusaha yang memanfaatkan hutan secara tidak bijak. Kepentingan mahluk hidup dibidang ekonomi dalam usaha kegiatan pemanfaatan kawasan hutan akan memberikan dampak yang negatif bagi kemanfaatan kawasan hutan serta untuk kehidupan makhluk hidup. Penebangan liar merupakan Penebangan pohon di kawasan hutan yang dilakukan tanpa izin dan menyalahi norma serta kaidah hukum yang berlaku, sehingga hutan akan kehilangan fungsi pokok sebagai paru-paru dunia.

Penebangan kawasan hutan secara liar tersebut akan mengakibatkan banyak terjadi bencanabencana alam seperti banjir, tanah longsor, erosi dan lain sebagainya. Tidak hanya terjadi bencana alam saja, tapi dapat mengakibatkan tanah yang mutunya turun, areal dalam kawasan hutan yang semakin menyempit dikarenakan perambatan dari hutan, pendapatan dari masyarakat disekitar hutan semakin menurun, serta dampak lainnya yaitu kemampuan dari biosfer untuk menyerap karbondioksida semakin berkurang sehingga berakibat penambahan atau pemanasan pada suhu yang lebih tinggi pada permukaan bumi, hal tersebut menjadikan paru-paru dunia saat ini tidak lagi hutan. Indonesia telah memiliki beberapa peraturan perundang-undangan yang mengatur tentang sanksi dan larangan dari pelaku atas perbuatan melanggar hukum dari penebangan pohon di hutan dengan cara liar yaitu diatur dalam kaidah norma di Indonesia, salah satunya Undang-undang tentang Kehutanan Nomor 41/1999 serta Undang-Undang tentang Pencegahan dan Pemberatasan Perusakan Hutan Nomor 18/2013. Dengan adanya aturan tersebut diatas telah mengatur mengenai larangan-larangan serta sanksi bagi pelaku penebangan hutan secara liar, namun masih banyak juga para oknum yang membandel dengan tetap melakukan aksi penebangan kawasan hutan secara brutal dan liar. Berdasarkan latar belakang di atas, penelitian ini bertujuan untuk mengetahui bentuk pengaturan tentang larangan penebangan hutan secara liar dan untuk mengetahui penerapan sanksi bagi pelaku penebangan hutan secara liar.

\section{METODE PENELITIAN}

Penelitian ini menggunakan metode Penelitian Hukum Normatif karena mengkaji dengan menggunakan studi kepustakaan berupa sumber-sumber hukum. Pendekatan masalah yang digunakan dalam penelitian ini adalah pendekatan perundang-undangan dan pendekatan konseptual. Adapun bahan hukum yang digunkan yakni:

1. Bahan hukum primer yang digunakan dalam penelitian ini adalah bahan-bahan Hukum yang mempunyai kekuatan mengikat berupa Undang-Undang Kehutanan Nomor 41 Tahun 1999, Undang-Undang Perlindungan dan Pengelolaan Lingkungan Hidup Nomor 32 Tahun 2009, Undang-Undang Pencegahan dan Pemberantasan Perusakan Hutan Nomor 18 Tahun 2013 dan PP Perlindungan Hutan Nomor 28 Tahun 1985.

2. Bahan Hukum Sekunder yang digunakan yaitu bahan hukum bersumber kepustakaan, berupa literatur-literatur hukum, jurnal hukum, internet maupun dokumen-dokumen sesuai dengan apa yang diteliti.

Teknik pengumpulan bahan hukum yang digunakan dalam penelitian ini adalah teknik dokumentasi yang dilaksanakan dengan cara menginventarisasi dan mengkatagorisasi bahan-bahan hukum baik berupa peraturan perundang-undangan, literatur-literatur maupun bahan hukum lainnya yang berkaitan dengan akibat hukum penebangan hutan secara liar. Selanjutnya dilakukan dengan metode pencatatan yaitu dengan cara mengutip, meringkas, dan memberikan ulasan-ulasan dengan topik bahasan. Setelah bahan hukum terkumpul, selanjutnya dianalisis dengan teknik sistematis berpadu dengan argumentasi secara hukum dengan berdasarkan dari logika hukum yang induktif dan deduktif serta akan dituangkan deskriptif yaitu penyajiannya akan dirancang dengan konsep serta penggambaran secara rinci mengenai aspek tertentu yang akan berhubungan dengan masalah selanjutnya akan dituangkan dalam bentuk skripsi. 


\section{HASIL DAN PEMBAHASAN}

\section{Pengaturan Larangan Penebangan Hutan Secara Liar}

Hutan merupakan satu kesatuan dari ekosistem di bumi dengan kawasan lahan yang isinya sumber alam hayati dengan didominan dari sekelompok alam dilingkungannya, yang tidak akan bisa terpisahkan satu dengan yang lainnya. Perlindungan kawasan hutan adalah suatu upaya guna melindungi hutan dari adanya kerusakan dan mengembalikan karakteristik serta fungsi hutan seperti sediakala. Perlindungan hutan tidak hanya berfungsi mencegah ancaman dari manusia, tetapi juga dari hama maupun penyakit serta bencana-bencana alam. Perlunya perlindungan hutan agar tidak terjadinya kerusakan-kerusakan pada hutan. Menjaga kelestarian kawasan hutan, melestarikan hasil pemanfaatan kawasan hutan serta lingkungan di sekitar hutan, untuk memiliki fungsi produksi, konservasi serta lindung untuk tercapainya tujuan pemerintah secara lestari dan optimal yang merupakan bentuk dari pelaksanaan perlindungan dari kawasan hutan (Redi, 2015). Beberapa lembaga dari swasta dan negeri yang bisa melakukan perlindungan terhadap hutan, sebagai berikut:

a. Pemerintah

Mengatur mengenai perlindungan hutan, baik internal atau didalam hutan maupun eksternal atau diluar kawasan hutan serta dengan perlindungan dari hutan pada hutan Negara serta pemerintah sebagai pelaksananya.

b. Izin usaha oleh pemegang izin. Pemanfaatan dari hutan dan pihak-pihak yang menerima wewenang, yaitu diwajibkan melindungi hutan dalam area kerjanya.

c. Pemegang hak. Dimana ia melakukan perlindungan hutan pada hutan hak (S, 2003)

Usaha-usaha agar melindungi hutan dari kerusakan yaitu tidak melakukan penebangan hutan secara liar dalam dalil apapun, melakukan reboisasi dan peremajaan tanaman tua, melakukan tebang pilih, membatasi izin-izin untuk penebangan pohon secara selektif bagi para pengusaha dimana jika pengusaha melanggar izin maka diberikan sanksi sesuai hukum yang berlaku.

Hutan perlu dijaga kelestariannya agar hutan tidak mengalami kerusakan, salah satu perbuatan yang mengakibatkan kerusakan pada hutan yaitu penebangan hutan yang dilakukan secara liar, larangan-larangan penebangan hutan secara liar terdapat dalam ketentuan Pasal 50 ayat (3) huruf c dan e Undang-undang Kehutanan Nomor 41 Tahun 1999, Pasal 69 ayat (1) huruf a Undang-undang Perlindungan dan Pengelolaan Lingkungan Hidup, Pasal 12 huruf a, b, dan c, Pasal 19 huruf b dan c Undang-undang Pencegahan dan Pemberantasan Perusakan Hutan nomor 18 Tahun 2013 serta Pasal 9 ayat (2) Peraturan Pemerintah Nomor 28 Tahun 1985 tentang Perlindungan Hutan.

Penebangan hutan secara liar merupakan suatu bentuk pelanggaran terhadap pelestarian fungsi hutan, penebangan liar dikatakan pelanggaran karena telah melanggar larangan-larangan yang telah ditentukan dan melakukan suatu tindakan menurut kehendak sendiri tanpa memperhatikan peraturanperaturan yang telah dibuat. Dengan dilanggarnya aturan mengenai larangan-larangan penebangan pohon di hutan yang dilakukan secara liar tersebut maka tindakan dari penebangan pohon di hutan yang dilakukan secara liar dapat dikategorikan sebagai bentuk pelanggaran terhadap pelestarian fungsi hutan yang mana dalam pengaturan larangan-larangan tersebut di buat agar hutan tidak mengalami kerusakan dan fungsi hutan dapat terlestarikan. Dengan adanya penebangan hutan secara liar maka akan mengakibatkan tidak terlestarinya fungsi hutan yang secara tidak langsung mengakibatkan menurunnya fungsi hutan. Hutan memiliki 3 fungsi yaitu fungsi produksi, fungsi konservasi, dan fungsi lindung. Perlu adanya suatu pelestarian fungsi hutan agar hutan memberikan banyak manfaat bagi makhluk hidup. Manfaat hutan yaitu berupa manfaat langsung dan tidak langsung.

a. Manfaat langsung

Manfaat langsung adalah manfaat yang dapat dirasakan atau dinikmati oleh masyarakat dengan cara langsung sehingga akan dapat memanfaatkan dan menggunakan hasil hutan, seperti kayukayu yang merupakan penghasilan utama hutan, serta berbagai hasil panen dari hutan lainnya, seperti madu alami, getah dari pohon karet, buah-buahan, rotan dan lain sebagainya.

b. Manfaat secara tak langsung

Manfaat yang tak langsung dinikmati oleh mahluk hidup, akan tetapi menikmati keberadaan dari hutan itu sendiri. Seperti mencegah terjadi erosi, dapat mengatur tata air, dapat memberikan manfaat di sektor pariwisata, mencegah banjir dan tanah longsor, menambah devisa lain serta manfaat lainnya. 
Menurut Forrest Watch Indonesia (FWI) dalam (Nurdjan, 2008:14), penebangan liar terdiri atas 2 bentuk, dimana penebangan pohon di hutan yang dilakukan secara liar dilakukan oleh operator yang sah melanggar ketentuan hukum yang berlaku dalam izin yang sudah dimiliki, dengan melibatkan para oknum pencuri kayu, dengan menebangi pohon-pohon di hutan oleh para oknum tersebut yang tidak memiliki izin legal untuk menebangi pohon-pohon di hutan.

\section{Penerapan Sanksi Bagi Pelaku Penebangan Hutan Secara Liar}

Sanksi merupakan hukuman bagi pelanggar ketentuan undang-undang. Sanksi dapat berupa sanksi administratif, sanksi perdata dan sanksi pidana (Hamzah, 2008:138). Sanksi-sanksi yang dikenakan bagi pelaku yang melakukan penebangan hutan secara liar dapat berupa sanksi perdata, sanksi administratif dan sanksi pidana yang mana diatur dalam Undang-undang Kehutanan, Undang-undang Perlindungan dan Pengelolaan Lingkungan Hidup, Undang-undang Pencegahan dan Pemberantasan Perusakan Hutan, dan PP Perlindungan Hutan Nomor 28 Tahun 1985.

Sanksi Perdata tidak diatur dengan cara khusus dalam PP Perlindungan hutan Nomor 28 Tahun 1985, namun telah diatur dalam Undang-undang Kehutanan. Penerapan sanksi perdata bagi pelaku yang melakukan perbuatan yang menyebabkan perusakan hutan salah satunya yaitu penebangan liar diatur dalam ketentuan Pasal 80 ayat (1) Undang-undang Kehutanan dan Pasal 87 ayat (1) Undangundang Perlindungan dan Pengelolaan Lingkungan Hidup. Sesuai ketentuan pasal tersebut dipertegas siapa-siapa saja yang dapat dimintai pertanggungjawaban terhadap kerusakan hutan. Yang dapat dimintai pertanggungjawaban terhadap kerusakan hutan adalah orang atau oknum yang bertanggung jawab atas terjadinya kerusakan hutan. Penanggung jawab dari perbuatan tersebut diwajibkan menjalankan kewajiban dengan membayar berupa uang sebagai bentuk ganti kerugian kepada Negara, kemudian uang tersebut digunakan untuk pemulihan kondisi hutan, tindakan lain yang diperlukan dan untuk Rehabilitiasi (S, 2003:166). Ganti rugi dengan dibebankan biaya ini bertujuan agar pemegang izin lebih memperhatikan azas kelestarian lingkungan dan selalu menjaga hutan dan melestarikan agar tetap menjadi paru-paru dunia.

Penerapan sanksi administratif bagi pelaku yang melakukan perbuatan yang menyebabkan perusakan hutan salah satunya yaitu penebangan liar diatur dalam ketentuan Pasal 80 ayat (2) Undang-undang Kehutanan dan Pasal 76 ayat (1) Undang-undang Perlindungan dan Pengelolaan Lingkungan Hidup. Lembaga pemerintah yang memiliki wewenang yakni Menteri Kehutanan ataupun Kantor Wilayah Departemen yang memeiliki wewenang untuk menjatuhkan sanksi administratif seperti pemegang izin usaha pemanfaatan kawasan, pemanfaatan jasa terhadap lingkungan, usaha pemanfaatan dari hasil hutan atau izin pemungut (S, 2003). Unsur dari pelanggaran sanksi yang dapat dikenakan sanksi administratif, yaitu:

1. Adanya penyimpangan perbuatan yang melanggar dan menyimpang dari ketentuan yang berlaku

2. Kewajiban yang telah ditentukan tidak terpenuhi dan

3. Adanya unsur kelalaian atau kesengajaan dari pemegang Hak Penguasaan atas hutan dan atau eksploitas hutan dari pemegang izin.

Hukuman penjara, kurungan, denda, dan benda yang akan dirampas dimana digunakan untuk melakukan perbuatan pidana merupakan hukuman atau sanksi yang akan dikenakan kepada pelaku penebangan pohon di hutan secara liar. Sanksi yang diterapkan dalam hukum pidana bagi pelaku yang melakukan penebangan hutan secara liar diatur dalam ketentuan Pasal 78 ayat (2) Undang-undang Kehutanan, Pasal 98 Undang-undang Perlindungan dan Pengelolaan Lingkungan Hidup, Pasal 82 ayat (1) huruf c Undang-undang Pencegahan dan Pemberantasan Perusakan Hutan. Ketiga perundangundangan tersebut mengatur tentang hukuman penjara dan denda sedangkan dalam Peraturan Pemerintah Nomor 28 tahun 1985 tentang Perlindungan Hutan mengatur tentang hukuman penjara dan denda, hukuman kurungan, beserta benda yang akan dirampas dimana digunakan oleh pelaku untuk melakukan perbuatan yang melanggar ketentuan pidana. Pasal 18 ayat (1) mengatur hukuman penjara dan denda, Pasal 18 ayat (4) mengatur hukuman penjara dan Pasal 18 ayat (7) mengatur perampasan benda akibat dari perbuatan melanggar ketentuan pidana.

\section{SIMPULAN DAN SARAN \\ 1. Simpulan}


Larangan-larangan perusakan hutan salah satunya yaitu penebangan hutan secara liar sudah diatur dalam hukum positif Indonesia yakni Pasal 50 ayat (3) huruf c dan e Undang-undang Kehutanan, Pasal 69 ayat (1) huruf a Undang-undang Perlindungan dan Pengelolaan Lingkungan Hidup, Pasal 12 huruf a, b dan c, Pasal 19 huruf b dan c Undang-undang Pencegahan dan Pemberantasan Perusakan Hutan dan Pasal 9 ayat (2) Peraturan Pemerintah Nomor 28 Tahun 1985 tentang Perlindungan Hutan. Kemudian, berdasarkan uraian di atas, apabila seseorang terbukti telah melakukan penebangan hutan secara liar maka dikenakan:

a. Sanksi Perdata, yakni dikenakan Pasal 80 ayat (1) Undang-undang Kehutanan 41 Tahun 1999.

Pasal tersebut dikenakan dikarenakan Undang-undang Kehutanan merupakan suatu aturan khusus mengenai Kehutanan, apabila dibandingkan dengan Undang-undang Perlindungan dan Pengelolaan Lingkungan Hidup.

b. Sanksi Administratif, dikenakan Pasal 80 ayat (2) Undang-undang Kehutanan 41 Tahun 1999. Sanksi administratif juga menggunakan aturan khusus yaitu Undang-undang Kehutanan 41 Tahun 1999.

c. Sanksi Pidana, yakni dikenakan Pasal 82 ayat (1) huruf c Undang-undang Pencegahan dan Pemberantasan Perusakan Hutan 18 Tahun 2013.

Dikenakannya Pasal 82 ayat (1) huruf c karena ketentuan Undang-undang ini merupakan lex specialis (ketentuan khusus) dari Undang-undang Nomor 41 Tahun 1999 tentang Kehutanan.

\section{Saran}

Melalui penelitian ini, diharapkan kepada masyarakat agar lebih peduli terhadap kelestarian lingkungan hidup, salah satunya yaitu hutan agar tidak terjadi bencana alam karena salah satu penyebab terjadinya bencana alam yaitu penebangan hutan secara liar. Selanjutnya, kepada pemerintah diharapakan agar mengadakan sosialisasi-sosialisasi kepada masyarakat mengenai pentingnya menjaga kelestarian hutan dan para pengusaha yang mengelola sumber daya hutan agar tidak mengekploitasi kekayaan-kekayaan alam secara berlebihan. Kemudian, kepada penegak hukum agar lebih tegas dalam menegakkan hukum bagi pelaku penebangan hutan yang dilakukan secara liar, guna memberikan efek jera bagi pelaku tanpa pandang bulu.

\section{DAFTAR PUSTAKA}

Boyle, A. (2012). Human rights and the environment: Where next? European Journal of International Law, 23(3), 613-642.

Carvalho, E. A. R., Mendonça, E. N., Martins, A., \& Haugaasen, T. (2020). Effects of Illegal Logging on Amazonian Medium and Large-sized Terrestrial Vertebrates. Forest Ecology and Management, 466(January), 118105.

Hamzah, A. (2008). Terminologi Hukum Pidana. Jakarta: Sinar Grafika.

Iskandar. (2015). Hukum Kehutanan. Bandung: Mandar Maju.

Nurdjan, I. G. M. (2008). Korupsi dan Illegal Logging dalam Sistem Desentralisasi. Yogyakarta: Pustaka Pelajar.

Rahmadi, T. (2013). Hukum Lingkungan di Indonesia. Jakarta: Rajawali Pers.

Redi, A. (2015). Hukum Sumber Daya Alam dalam Sektor Kehutanan. Jakarta: Sinar Grafika.

S, S. H. (2003). Dasar-Dasar Hukum Kehutanan Edisi Revisi. Jakarta: Sinar Grafika.

Sun, C. (2006). State statutory reforms and retention of prescribed fire liability laws on U.S. forest land. Forest Policy and Economics, 9(4), 392-402.

Supriatna, J., Shekelle, M., Fuad, H. A. H., Winarni, N. L., Dwiyahreni, A. A., Farid, M., ... Zakaria, Z. (2020). Deforestation on the Indonesian Island of Sulawesi and the Loss of Primate Habitat. Global Ecology and Conservation, 24, 1-14.

Tacconi, L., Rodrigues, R. J., \& Maryudi, A. (2019). Law enforcement and deforestation: Lessons for Indonesia from Brazil. Forest Policy and Economics, 108(September 2018), 101943.

Vardeman, E., \& Runk, J. V. (2020). Panama's Illegal Rosewood Logging Boom from Dalbergia Retusa. Global Ecology and Conservation, 23(e01098), 1-14.

Undang-Undang Nomor 41 Tahun 1999 tentang Kehutanan.

Undang-Undang Nomor 39 Tahun 2009 tentang Perlindungan dan Pengelolaan Lingkungan Hidup.

Undang-Undang Nomor 18 Tahun 2013 tentang Pencegahan dan Pemberantasan Perusakan Hutan.

Peraturan Pemerintah Nomor 28 Tahun 1985 tentang Perlindungan Hutan. 